\title{
TOXIC ORGANIC COMPOUNDS FROM ENERGY PRODUCTION
}

\author{
PROGRESS REPORT \\ TO \\ THE U. S. DEPARTMENT OF ENERGY \\ FROM \\ INDIANA UNIVERSITY \\ DOE / E. $/ 60530--5$ \\ DE92 003551
}

Ronald A. Hites

Distinguished Professor of Public and Environmental Affairs and Professor of Chemistry

School of Public and Environmental Affairs

Indiana University

Bloomington, Indiana 47405

Phone: 812-855-0193; Fax: 812-855-1076

Current Grant Number: DE-FG02-87ER60530

ENDORSEMENTS:

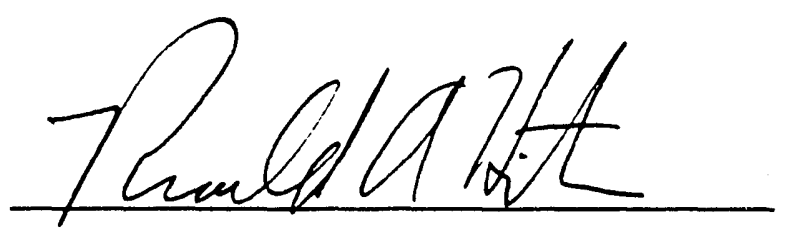

Ronald A. Hites, Distinguished Professor

George Walker

Vice President for Research and

Dean of the Graduate School

Research and the University Graduate School

Indiana University

P.C. Box 1847

Bloomington, IN 47402

Phone: 812-855-3961

September 20, 1991 
PREFACE

This is a proposal for renewal of DOE grant DE-FG02-87ER60530. This proposal was written by Professor Hites and by seven of his students:

\author{
Tony Borgerding \\ Louis Brzuzy \\ Kelly Dodson \\ Carolyn Koester \\ Mark Krieger \\ Staci Massey \\ Voon Ong
}

It is a pleasure to acknowledge their assistance.

\title{
DISCLAIMER
}

This report was prepared as an account of work sponsored by an agency of the United States Government. Neither the United States Government nor any agency thereof, nor any of their employees, makes any warranty, express or implied, or assumes any legal liability or responsibility for the accuracy, completeness, or usefulness of any information, apparatus, product, or process disclosed, or represents that its use would not infringe privately owned rights. Reference herein to any specific commercial product, process, or service by trade name, trademark, manufacturer, or otherwise does not necessarily constitute or imply its endorsement, recommendation, or favoring by the United States Government or any agency thereof. The views and opinions of authors expressed herein do not necessarily state or reflect those of the United States Government or any agency thereof. 
TABLE OF CONTENTS

I. OVERVIEW $\ldots \ldots \ldots \ldots \ldots \ldots \ldots \ldots \ldots \ldots \ldots \ldots \ldots \ldots \ldots$

I.1. Summary of Objectives and Progress $\ldots \ldots \ldots \ldots \ldots \ldots \ldots$

I.2. Publications Supported by this Project in 1990 and $1991 \ldots \ldots$. . 2

I.3. Graduate Students, Supported by this Project, Whose Training was completed in 1990 and 1991 . . . . . . . . . . . . . 3

II. CURRENT WORK AND FUTURE PLANS $\ldots \ldots \ldots \ldots \ldots \ldots \ldots$

II.1. Development and Optimization of an Electron Capture, Negative Ionization Source $\ldots \ldots \ldots \ldots \ldots \ldots \ldots \ldots$

II.2. Environmental Analysis with Continuous Flow Fast Atom Bombardment ........................ 6

II.3. Removal Mechanisms of Atmospheric Polychlorinated Dibenzo-p-Dioxins and Polychlorinated Dibenzofurans . . . . . 8

II.4. Chlorinated Dioxins and Furans in Soil Near Roads: An Apportionment of Mobile Sources . . . . . . . . . . 10

II.5. Vapor Phase Photolysis of Chlorinated Organics in the Atmosphere ......................... 12

II.6. The Use of Tree Bark as a Bioindicator for Atmospheric Polycyclic Aromatic Hydrocarbons . . . . . . . . . . . . . . . 14 


\section{OVERVIEW}

\section{1. SUMMARY OF OBJECTIVES AND PROGRESS}

The U.S. Department of Energy's Office of Health and Environmental Research (OHER) has supported work in our laboratory since 1977. The general theme of this program has been the identification of potentially toxic organic compounds associated with various combustion effluents, following the fates of these compounds in the environment, and improving the analytical methodology for making these measurements. The paragraphs which follow and Section II summarize our work over the last year.

We have been interested in the atmospheric fate of toxic organic compounds produced by combustion for many years. Current work focuses on the fate of combustionproduced polychlorinated dioxins and dibenzofurans (PCDD/F). Our previous work centered on measuring the atmospheric concentrations of these compounds and developing information on the vapor-particle partitioning process that takes place in the atmosphere. Currently, we are studying wet and dry deposition processes of PCDD/F. We have found that these processes are highly temperature dependent.

To complete the picture of the atmospheric behavior of dioxins and furans, we are also studying their photodegradation. We have learned that PCDD/F are stable when adsorbed to fly ash and to atmospheric particulate matter. Thus, transformations in ambient atmospheric samples must be attributable to vapor phase photodegradation. Experiments, which will use a photoreactor on-line to a mass spectrometer, are underway to confirm this idea.

The main sources of chlorinated dioxins and furans to the atmosphere are certainly combustion-systems. It is not clear, however, what the contributions from different combustion systems are. In an attempt to separate mobile from stationary sources, we have measured the concentrations of these compounds in soils taken next to heavily traveled roads. We estimate that about $5 \%$ of the dioxins in soils are found next to roadways, which suggests that mobile sources are not important.

We are investigating triple quadrupole mass spectrometry as a tool for the analysis of environmental samples. Experiments are underway in two areas: (a) Molecules are ionized under electron capture conditions and selected, collisionally produced fragment ions are measured. This combination of sensitivity (achieved by the electron capture process) and selectivity (achieved by the tandem mass spectrometry process) produce subpicogram sensitivities without extensive sample clean-up. (b) There has been considerable interest in the last 15 years in combining liquid chromatography with mass spectrometry; few of these techniques work routinely. Recent work indicates that continuous flow fast atom bombardment ionization may be the optimum solution. Thus, we have interfaced microcolumn liquid chromatography with continuous flow FAB mass spectrometry. We have also demonstrated the value of this interface for flow injection analysis.

We have begun studies of the accumulation of toxic organic compounds by vegetation. Our early work focused on the accumulation of PCB by tree bark; the results indicated that tree bark readily bioaccumulated vapor phase organic air pollutants due to the 
presence of suberin, a complex fatty substance, in the outer bark. To further understand the process of vegetative bioaccumulation, we are now working with polycyclic aromatic hydrocarbons (PAH). Because of their wide range of vapor pressures, we are able to study a single class of compounds in which some members exist primarily in the vapor phase while others exist as particulates in the atmosphere. Our data to date suggest that there is an excellent correlation between the tree bark PAH concentration and the atmospheric particulate PAH concentration. This may indicate that adsorption of particulate PAH plays a larger role in bioaccumulation than does absorption of gas phase PAH. Alternatively, it may indicate that the more lipophilic, higher molecular weight PAH are more readily bioaccumulated.

The analysis of trace levels of semi-volatile organic compounds in the atmosphere is becoming increasingly important. Unfortunately, the measurement technology for these compounds is cumbersome, time consuming, and prone to contamination. Thus, we have developed a sampling device based on denuder technology. In essence, the device is a 30 meter capillary GC column which has been chopped up into $20-30 \mathrm{~cm}$ lengths. All of these tubes are connected in parallel to a sampling pump and later to a gas chromatograph. The device is now working, and we are studying its operating parameters. Samples can be taken in less than 2-3 hours and analyzed in about an hour.

The projects on an improved sampler for semi-volatile compounds in the atmosphere; the wet and dry deposition of dioxins and furans from the atmosphere; the photodegradation and mobile sources of dioxins and furans; and on the bioaccumulation of PAH by tree bark are all responsive to OHER's interest in the "pathways and mechanisms by which energy-related agents move through and are modified by the atmosphere". The projects on gas chromatographic and liquid chromatographic tandem mass spectrometry are both responsive to OHER's interest in "new and more sensitive technologies for shemical measurements". DOE/OHER funds currently support the Ph.D. and Masters' theses of seven students. Clearly, funding from the Department of Energy for this project is absolutely essential for the healthy operation of our laboratory.

\section{2. PUBLICATIONS SUPPORTED BY THIS PROJECT IN 1990 AND 1991}

Comparative analysis of dioxins and furans by high resolution and electron capture mass spectrometry, Chemosphere, submitted; with C. J. Koester and R. L. Harless.

Natural and anthropogenic organic compounds in the global environment, in Global Atmospheric Chemical Change, C. N. Hewitt and W. T. Sturges, Elsevier Applied Science, in press; with E. L. Atlas, S.-M. Li, and L. J. Standley.

Reiationship between gas chromatographic retention indexes and computer-calculated physical properties of four classes of compounds, Analytical Chemistry, in press; with V. S. Ong.

Photodegradation of polychlorinated dioxins and dibenzofurans adsorbed to fly ash, Environmental Science and Technology, in press; with C. J. Koester. 
Chlorinated organic compounds in the atmosphere, in Organic Contaminants in the Environment, K. C. Jones, Elsevier Applied Science, in press; with L. J. Standley.

Chlordane accumulation in people, Environmental Science and Technology, 25, 1279-1285 (1991); with M. A. Dearth.

Depuration rates of chlordane compounds from rat fat, Environmental Science and Technology, 25, 1125-1128 (1991); with M. A. Dearth.

Complete analysis of technical chlordane using negative ionization mass spectrometry, Environmental Science and Technology, 25, 245-254 (1991); with M. A. Deart'h.

The environmental behavior of chlorinated dioxins and furans, Accounts of Chemical Research, 23, 194-201 (1990).

Polychlorinated biphenyls in tree bark, Environmental Science and Technology, 24, 666-671 (1990); with M. H. Hermanson.

Highly chlorinated dimethanofluorenes in technical chlordane and in human tissue, Joumal of the American Society for Mass Spectrometry, 1, 99-103 (1990); with M. A. Dearth.

An interlaboratory comparison of limits of detection in negative chemical ionization mass spectrometry, Organic Mass Spectrometry, 25, 191-196 (1990); with B. Arbogast and 9 others.

\section{3. GRADUATE STUDENTS, SUPPORTED BY THIS PROJECT, WHOSE TRAINING WAS COMPLETED IN 1990 AND 1991}

\section{Masters of Science}

Louis P. Brzuzy, 1991, Ph. D. Student, Indiana University, Bloomington, IN

Anne M. Starrett, 1990, Scientific Staff, Squibb Pharmaceutical Co., Princeton, NJ

Susan M. Visscher, 1990, Scientific Staff, Merck Pharmaceutical Co., Rahway, NJ

Doctors of Philosophy

Mark A. Dearth, 1990, Research Scientist, Ford Motor Co. 


\section{CURRENT WORK AND FUTURE PLANS}

\section{1. DEVELOPMENT AND OPTIMIZATION OF AN ELECTRON CAPTURE, NEGA- TIVE IONIZATION SOURCE}

Gas chromatographic mass spectrometry (GC-MS) is widely used for the identification, detection, and quantitation of toxic environmental contaminants. However, many of these toxic contaminants respond poorly under electron impact ionization conditions. Also, electron impact ionization often causes molecules to fragment extensively making molecular weight determination and, subsequently, compound identification arduous. Furthermore, ionization of the sample matrix together with trace levels of the analytes of interest often makes accurate quantitation difficult. It has been our experience that electron capture negative chemical ionization (ECNI) is a particularly selective and sensitive mode of ionization for the trace determination of organic environmental contaminants (1-4) and can be used to avoid the complications normally encountered when using electron impact ionization. The aim of this project is to implement this mode of ionization on our triple quadrupole mass spectrometer to take advantage of its tandem mass spectrometry (MS/MS) capability. By using MS/MS, we have an added degree of selectivity to help in identifying the analyte of interest and also reducing the amount of time spent on sample clean-up and preconcentration.

The triple quadrupole instrument used in this project is a VG $30-250$ system, equipped with a Hewlett Packard 5890 gas chromatograph. The capabilities of the instrument include electron impact and chemical ionization; however, it was not fitted with a dedicated chemical ionization source. Efforts are underway to develop and optimize a separate chemical ionization source on the instrument (specifically for work under ECNI conditions).

A dedicated chemical ionization (CI) ion source has been constructed solely for ECNI work by modifying one of the original electron impact ion sources. The CI source is smaller in internal volume and is cylindrically shaped with dimensions that measure $3 \mathrm{~mm}$ in height and $10 \mathrm{~mm}$ in diameter. A small ion source volume enables higher source pressures to be maintained in the ionization chamber while keeping the pressure in the analyzer region sufficiently low.

To assess the performance of the VG 30-250 mass spectrometer with this new CI source, mass spectra for several compounds were acquired and compared to those obtained on the HP 5985B GC-MS system operating under similar conditions (4). The HP 5985B system in our laboratory has proven to be a reliable instrument for ECNI work over the course of many years.

We noticed one commonality among the spectra of chlorinated compounds acquired on the VG 30-250. They were all dominated by an intense $\mathrm{Cl}^{-}(\mathrm{m} / \mathrm{z} 35$ ion) peak, unlike the spectra acquired on the HP 5985B, which showed very much less intense or no $\mathrm{Cl}^{-}$at all in some cases. An example of this is shown in Figure 1 for endosulfan I. This result indicated that dissociative resonance capture was more prevalent than its non-dissociative counterpart, which forms the molecular ion $\left(\mathrm{M}^{-}\right)$. This, in turn, suggested the $\mathrm{CI}$ source on the VG produced a higher mean electron energy distribution than the source on the HP 

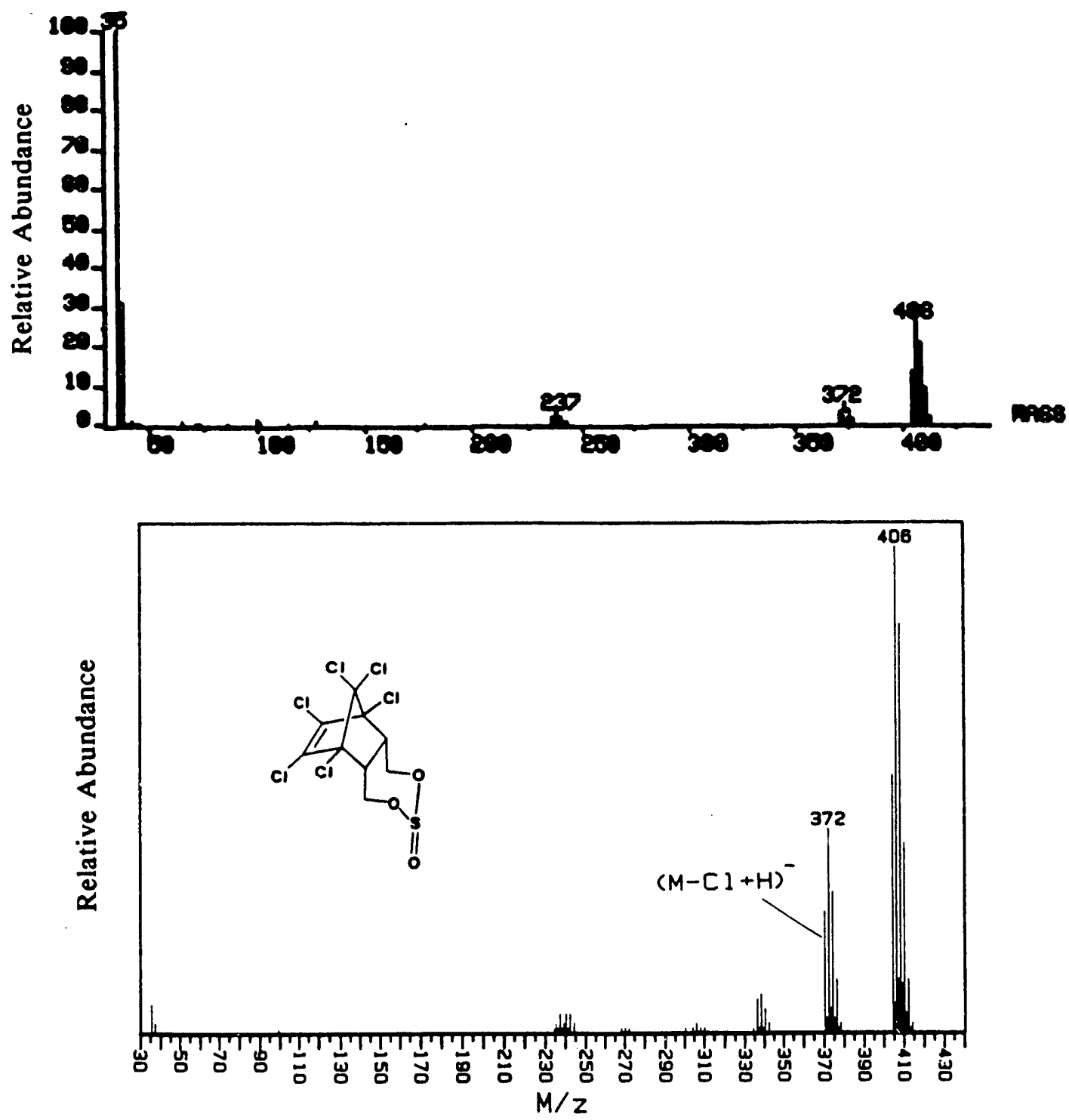

Figure 1. Mass spectra of endosulfan I (MW 404) acquired on the VG 30-250 (top) and the HP 5985B (bottom) at 100 degrees source temperature. 
5985B. However, it was still odd that no $\mathrm{Cl}^{-}$was formed from ionization of chlorinated compounds since non-dissociative resonance capture has been known to occur even at electron energies down to levels of $0.0 \mathrm{eV}(5)$. Clearly, this observation of different relative abundances of low to high mass ions in the spectra acquired on different instruments required further investigation.

There are basically 2 possible explanations about why there is a sharp dissimilarity in the spectra of the VG and HP instruments: (a) More non-dissociative resonance capture is occurring (thereby producing more molecular ions and high mass ions) in the ion source of the HP 5985B as a result of a lower electron energy distribution, or, (b) Similar amounts of low to high mass ions are produced in the two ion sources, but the differences in the spectra acquired on the HP 5985B arise due to the discrimination of low mass ions by the instrument. If the former was occurring then an understanding of the processes that control the production of a lower electron energy distribution would be an advantage and would subsequently enhance the reproducibility of ECNI spectra among different instrument types.

Instrumental parameters that may influence relative ion abundances include ion source temperature, ion source pressure, emission current (primary electron current), and electron energy of the primary electrons. However, when the emission current and electron energy were varied throughout the range available on the VG 30-250, no difference in the mass spectrum of the tuning compound was found. The effects of ion source temperatures and source pressures are currently being studied.

We are also studying the effects of different lens potentials on the transmission of low and high mass ions through the extraction optics of the 2 different instruments (VG 30250 and HP 5985B). We are complementing this study with computer-aided modeling of ion trajectories through both systems. This will aid us in determining if the differences in mass spectra obtained under otherwise similar electron capturing conditions (when using instruments made by different manufacturers) were due to mass discrimination by one particular system.

\section{References}

1. Dearth, M. A.; Hites, R. A. J. Am. Soc. Mass Spectrom. 1990, 1, 99-103.

2. Furlong, E. T.; Carter, D. S.; Hites, R. A. J. Great Lakes Res. 1988, 14, 489-501.

3. Swackhammer, D. L.; Charles, M. J.; Hites, R. A. Anal. Chem. 1987, 59, 913-917.

4. Stemmler, E. A.; Hites, R. A. Electron Capture Negative Ion Mass Spectra of Environmental Contaminants and Related Compounds; VCH: New York, 1988.

5. Christophorou, L. G.; Compton, R. N.; Hurst, G. S.; Reinhardt, P. W. J. Chem. Phys. 1966, 45, 536-547. 


\section{2. ENVIRONMENTAL ANALYSIS WITH CONTINUOUS FLOW FAST ATOM BOMBARDIMENT}

Studies in environmental organic chemistry have relied extensively on gas chromatographic mass spectrometry as a method of analysis. Although this technique is effective in terms of sensitivity, qualitative utility, and general durability, it is limited to compounds that are sufficiently volatile and thermally stable.

Unfortunately, in many environmental matrices, a high percentage of the total organic carbon is made up of compounds that do not have those physical properties. For example, a survey of leachates from hazardous waste sites in California showed that more than ninety percent of the total organic carbon was nonvolatile (1). Furthermore, the study of the metabolism of many organics is difficult because the products of the metabolic reaction are not amenable to GC-MS analysis. In general, as an organic compound becomes more oxidized, it becomes more difficult to analyze by GC-MS. Since there are many organic compounds in the environment that are not amenable to GC-MS analysis, a complete study of most environmental problems involving organic compounds is not possible using conventional means.

Introducing the analyte to the mass spectrometer in a condensed phase is an obvious way of getting around the problems associated with GC-MS. This has been achieved in several ways, including LC-MS interfaces such as thermospray and particle beam MS, electrospray ionization, and desorption techniques such as fast atom bombardment (FAB) and laser ionization MS (LIMS). Electrospray and desorption techniques have the advantage of being more sensitive to highly polar and ionic compounds, such as those not amenable to GC-MS.

We have attacked the problem of analyzing polar, thermally labile compounds using continuous flow FAB, a technique in which the analyte is introduced into the mass spectrometer in a flow of solvent which includes 5-10\% of a FAB matrix such as glycerol. We have used CF-FAB with capillary liquid chromatography since the flow rates for the two techniques are compatible. However, in some instances using tandem mass spectrometry provides sufficient information that analysis can be accomplished without chromatography, even for several analytes in a complex sample. By avoiding chromatography, sample analysis time is typically reduced to 3 minutes.

HPLC-grade water and methanol were mixed in various ratios with glycerol to make a $5 \%$ solution. This mixture was filtered and degassed by passing it through a 0.46 micron nylon membrane filter in a sonicating bath at reduced pressure. Iiquid flow is supplied through a 2 micron in-line iilter by an Isce micro-LC-500 syringe pump. The injection valve is a Valco CI $4 \mathrm{~W}$ fitted to inject a volume of $0.5 \mu \mathrm{L}$. If chromatography is done, a $0.320 \mathrm{~mm}$ i.d. X $10 \mathrm{~cm}$ octadecyl column from LC Packings is directly connected to the injection valve. Otherwise, a $0.075 \mathrm{~mm}$ i.d. fused silica tube is attached to the valve, which acts as a transfer line through which the sample flows to the mass spectrometer. The mass spectrometer is a 30-250 triple quadrupole from VG Masslab. For these experiments, the FAB ion source and an Ion Tech cold cathode saddle field gun were utilized. 
Several modifications to the source and probe were made to allow for contact of a sorbent pad with the tip of the CF-FAB probe. This sorbent pad absorbs excess liquid from the edge of the probe tip, preventing accumulation which can lead to sudden evaporation and unstable source pressure and ion signal. In addition, the flow of liquid is drawn to the pad by capillary action, further stabilizing the flow and, consequently, the ion current.

The sorbent pad is placed in a small cup that was welded into the source heating block, directly beneath the area in which the probe tip rests. In addition, new probe tips were designed that contain a $1.6 \mathrm{~mm}$ frit at the point of liquid introduction, and also shallow groove which assures that the initial flow will be in the direction of the sorbent pad. These modifications have led to much more stable flows and consequently to more sensitive and reproducible results.

The analytical efficiency of CF-FAB tandem mass spectrometry has been demonstrated in the analysis of linear alkylbenzenesulfonates (LAS). LAS are the largest group of anionic surfactants in production, with approximately 270,000 tons being produced annually, primarily for commercial use. They are an important group of compounds in the municipal wastewater treatment process.

Tandem mass spectrometry studies on LAS using a triple quadrupole instrument have shown that, upon collisionally induced dissociation, all LAS homologues fragment to an ethylene substituted benzenesulfonate ion as shown in Figure 1. Therefore, by scanning the parent ions of the ethylene benzenesulfonate, it is possible to quantitate for all of the LAS homologues simultaneously without prior chromatographic separation. Figure 2 shows a series of injections of various concentrations of $\mathrm{C}_{10} \mathrm{LAS}$, indicating the sensitivity and reproducibility of the technique, as weli as its ability to rapidly analyze samples. This method has been used to determine concentrations for each homologue in environmental samples.

We are currently developing similai approaches to analyze other groups of compounds that are of environmental importance. Several other compounds in the detergent industry, such as quaternary ammonium compounds, lignosulfonates, and fluorescent whitening agents, are also used commercially in large quantities and are important in municipal wastes. We are also studying compounds found in industrial wastes, such as dyes. Furthermore, methods will be developed to analyze for ionic organic compounds emitted to the environment from the petroleum industry, which includes a variety of aromatic and aliphatic carboxylic acids.

\section{Reference}

1. Brown, M.; Kim, I.; Roehl, R.; Sasinos, F.; Stephens, R. Chemosphere 1989, 19, 1921-1927. 

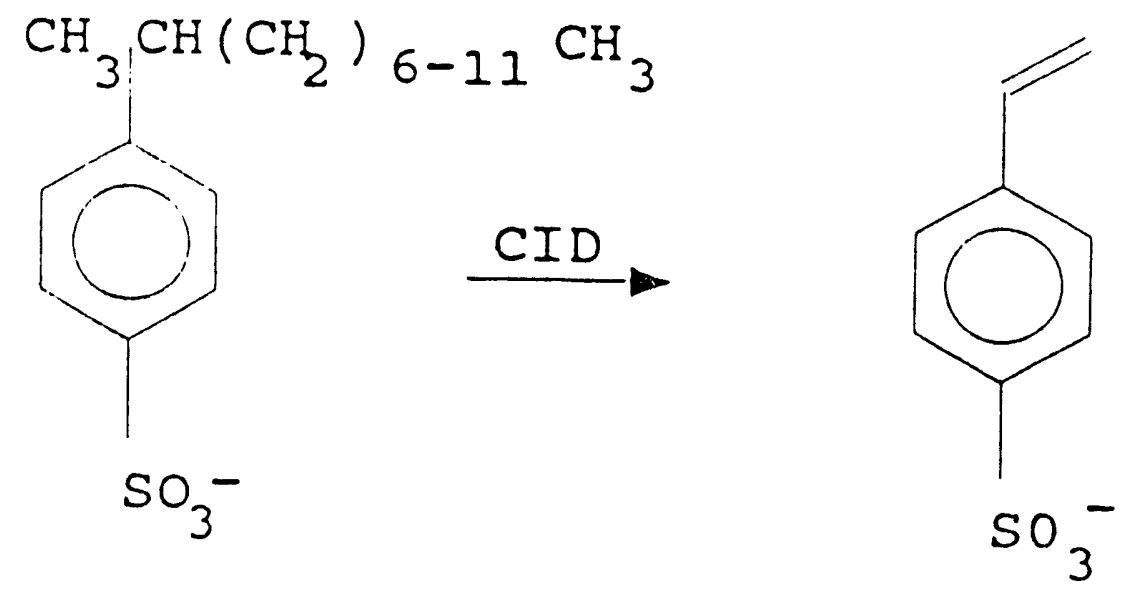

Figure 1. Fragmentation scheme of LAS using quadrupole tandem mass spectrometry.

$500 \mathrm{ng}$

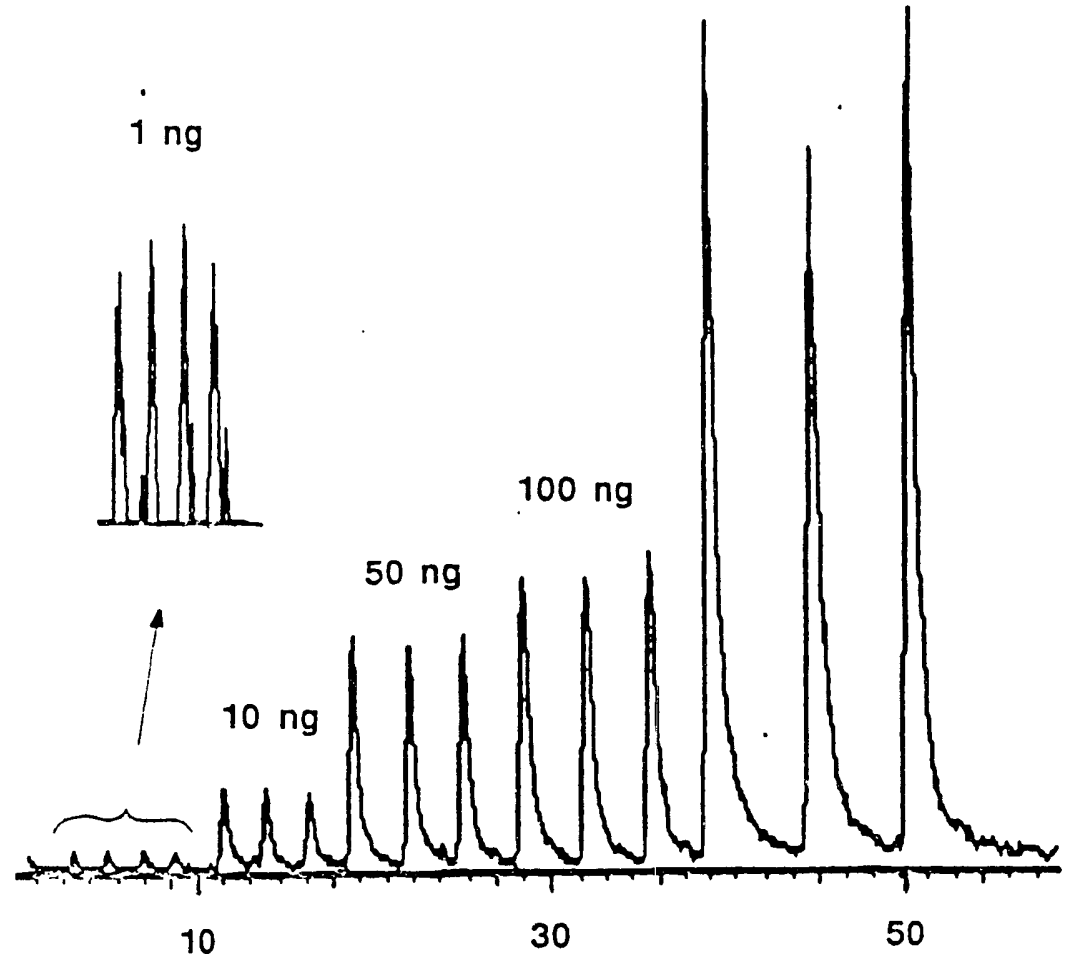

time $(\min )$

Figure 2. Parent-ion trace of replicate injections of $c_{10}$ LAS. 


\section{3. REMOVAL MECHANISMS OF ATMOSPHEKIC POLYCHLORINATED DIBEN- ZO-p-DIOXINS AND POLYCHLORINATED DIBENZOFURANS}

We have continued to study the mechanisms of removal of polychlorinated dibenzo$p$-dioxins and polycillorinated dibenzofurans (PCDD/F) from the atmosphere. From our studies of tive photodegradation of PCDD/F adsorbed to various fly ashes, we have concluded that particulate-bound PCDD/F do not photodegrade. Thus, the removal processes which we have r'osen to investigate are vapor-phase photodegradation, wet deposition, and dry deposition.

Previously, we investigated the wet deposition of PCDD/F in Bloomington, Indiana (1). While this study increased our knowledge of rain scavenging of PCDD/F, it was not clear if this study's results were representative of wet deposition in other locations. Thus, we sought to measure PCDD/F in rain collected in a more urban area: Indianapolis, Indiana. We expected to find higher concentrations of PCDD/F in Indianapolis rain. This would provide the opportunity to measure congener specific concentrations, scavenging ratios, and Henry's Law constants.

Rain samples were collected with a wet-only sampler. Particulates were immediately removed, in-situ, from rain water by a series of 1 micron glass fiber filters (GFF), which provides an operational definition of dissolved and particulate phases. The filtered rain water was then collected in $20 \mathrm{~L}$ glass carboys and later extracted with $\mathrm{CH}_{2} \mathrm{Cl}_{2}$. All extracts were prepared and analyzed by previously published methods $(1,2)$.

PCDD/F were measured in 15 rain samples. Peak specific PCDD/F cnncentrations for the dissolved and particulate phases were measured; however, because the profiles of $\mathrm{PCDD} / \mathrm{F}$ within a homologue are similar from sample to sample and because the relative ratios of the amounts of various $\mathrm{PCDD} / \mathrm{F}$ congeners to the total amount of $\mathrm{PCDD} / \mathrm{F}$ present in each sample are the same, we have chosen to quantitate PCDD/F as homologues.

The "average" PCDD/F profile for Indianapolis rain is shown in Figure 1, top. Because $\mathrm{PCDD} / \mathrm{F}$ concentrations are exponentially and inversely related to rainfall amount, we used a weighted average to determine this profile:

$$
\log C=\left(\Sigma V_{i} \log C_{i}\right) /\left(\Sigma V_{i}\right)
$$

where $\mathrm{C}$ is $\mathrm{PCDD} / \mathrm{F}$ concentration and $\mathrm{V}$ is the volume of rain. The total average $\mathrm{PCDD} / \mathrm{F}$ concentration was $130 \mathrm{pg} / \mathrm{L}$. The total concentration of dissolved $\mathrm{PCDD} / \mathrm{F}$ was $17 \mathrm{pg} / \mathrm{L}$; the total concentration of particulate bound PCDD/F was $110 \mathrm{pg} / \mathrm{L}$.

Figure 1, bottom, shows the average $\mathrm{PCDD} / \mathrm{F}$ profile of Bloomington rain. $\mathrm{PCDD} / \mathrm{F}$ concentrations in Indianapolis and Bloomington rains are similar. In addition, overall scavenging ratios (ratios of $\mathrm{PCDD} / \mathrm{F}$ air concentrations to $\mathrm{PCDD} / \mathrm{F}$ rain concentrations) in Indianapolis, which ranged from 9000 to 86000 , were comparable to scavenging ratios measured in Bloomington. As in Bloomington, $\mathrm{PCDD} / \mathrm{F}$ with higher levels of chlorination (that is, lower vapor pressures) were scavenged iy rain most efficiently. Henry's Law constants ranged from $1.5 \times 10^{-5}$ to $5.0 \times 10^{-8}$. Particulate scavenging (removing 


\section{INDIANAPOLIS RAIN \\ $(\mathrm{T}=19 \mathrm{C}, \mathrm{n}=15)$}

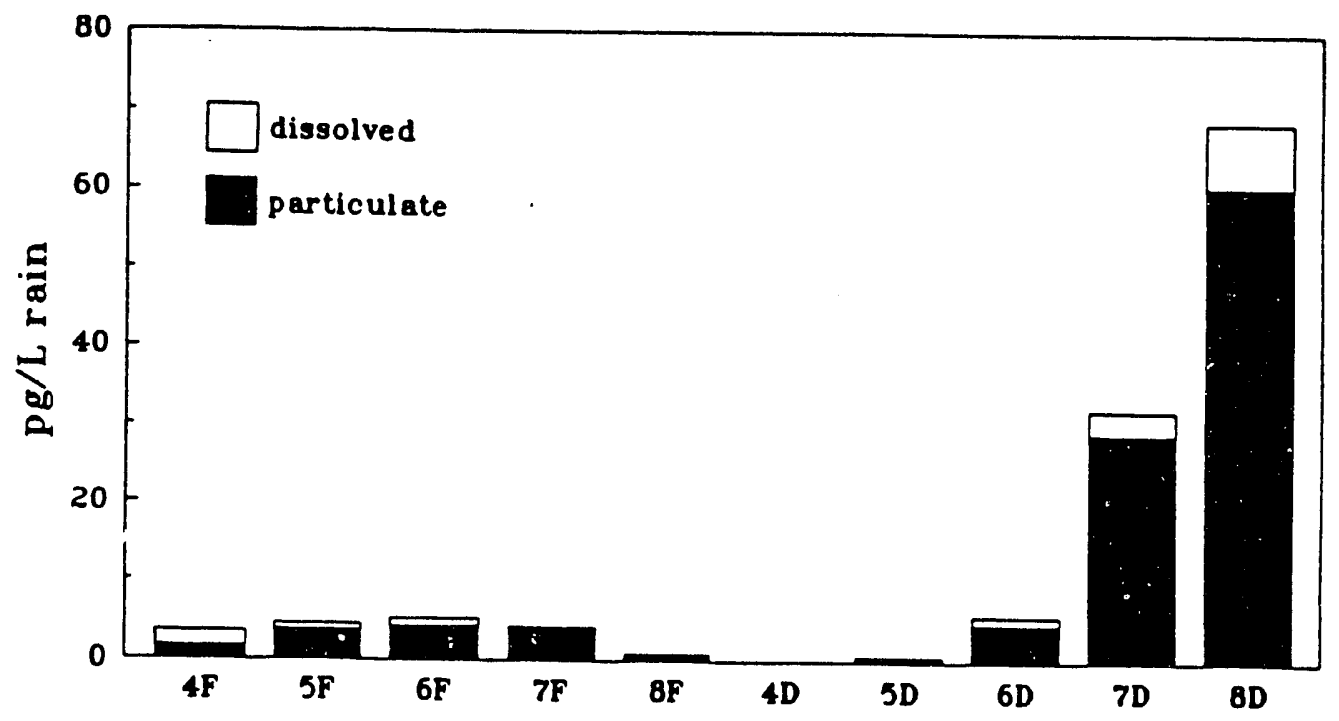

\section{BLOOMINGTON RAIN}

$(\mathrm{T}=22 \mathrm{C}, \mathrm{n}=13)$

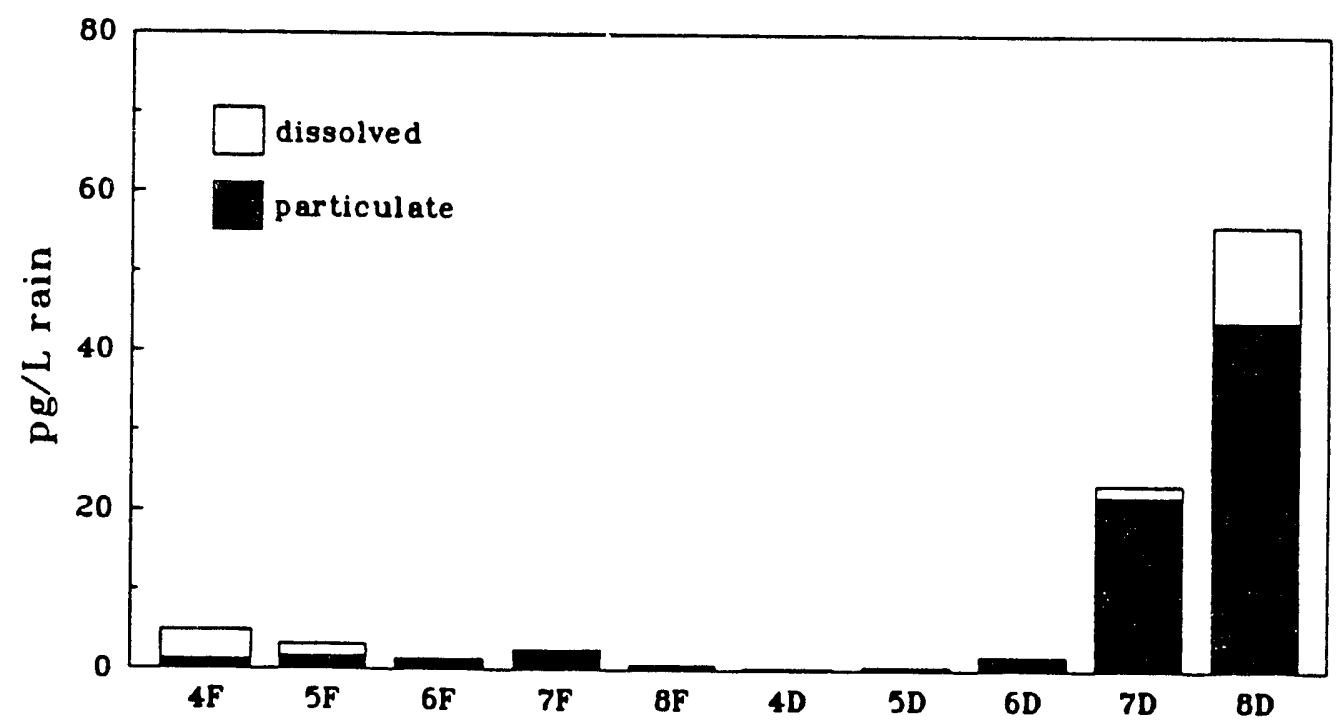

Figure. 1. Average Indianapolis (top) and Bloomington (bottom) rain profiles. PCDD/F are quantitated as homologues and concentrations are in $\mathrm{pg} / \mathrm{L}$ rain. Particulate-bound $\overline{\mathrm{P}} \overline{\mathrm{DD}} \overline{\mathrm{D}} / \overline{\mathrm{F}}$ concentrations are represented by black bars; dissolved concentrations are represented by white bars. Numbers indicate level of chlorination. "D" indicates PCDD and "F" indicates PCDF. 
approximately $50 \%$ of tetrachlorofurans to $90 \%$ of octachlorodioxin) was the dominant wet removal mechanism. Because the percentage of PCDD/F bound to particles is affected by temperature (3), rain scavenging of particulate-bound PCDD/F is affected by temperature. We have observed that the amount of particulate-bound PCDD/F removed by rain correlates with inverse temperature, in agreement with theory.

Based on measurements of PCDD/F in air, we suspected that dry deposition is also an important removal mechanism. No data exists regarding the dry deposition of $\mathrm{PCDD} / \mathrm{F}$. Therefore, we measured PCDD/F dry seposition. Dry deposition samples were collected with inverted frisbee samplers, each w an area of $0.13 \mathrm{~m}^{2}$. The inverted frisbees were covered with aluminurin foil and coat $/ 1$ with $0.2 \mu \mathrm{L} / \mathrm{cm}^{2}$ of mineral oil. Dry deposition was collected during 4 to 5 day interv:ds of no rain. PCDD/F were removed from the samplers with glass wool wipes and $\mathrm{CH}_{2} \mathrm{Cl}_{2}$ rinses. The glass wool was then Soxhlet extracted with $\mathrm{CH}_{2} \mathrm{Cl}_{2}$ and the sample e"iracts were prepared and analyzed by standard laboratory procedures.

Average PCDD/F homologue profiles of dry deposition measured in Bloomington (18 samples) and Indianapolis (4 samples) are shown in Figure 2 . In both places, total fluxes of PCDD/F were $100 \mathrm{ng} /\left(\mathrm{m}^{2} \mathrm{yr}\right)$. However, PCDD/F concentrations measured in Indianapolis are higher by a factor of approximately 2 when compared witil samples collected at comparable temperatures in Bloomington. As with wet deposition, dry deposition is also correlated with inverse temperature.

Fluxes of PCDD/F removed by wet and dry deposition are comparable. The total fluxes of PCDD/F removed by rain in Indianapolis and Bloomington, assuming an average rainfall rate of $100 \mathrm{~cm} / \mathrm{yr}$, are $130 \mathrm{ng} /\left(\mathrm{m}^{2} \mathrm{yr}\right)$ and $110 \mathrm{ng} /\left(\mathrm{m}^{2} \mathrm{yr}\right)$, respectively. The total flux of PCDD/F removed by dry deposition in both Indianapolis and Bloomington is 100 $\mathrm{ng} /\left(\mathrm{m}^{2} \mathrm{yr}\right)$. Thus, both wet and dry deposition are of equal importance in the removal of PCDD/F from the atmosphere and should be considered when assessing human exposure to $\mathrm{PCDD} / \mathrm{F}$.

\section{References}

1. $\quad$ Eitzer, B. D. and Hites, R. A., Environ. Sci. Technol, 1989, 23, 1396-1401.

2. Czuczwa, J. M. and Hites, R. A., Environ. Sci. Technol., 1984, 18, 444-450.

3. Yamasaki, H., Kuwata, K., and Miyamoto, H., Environ. Sci. Technol., 1982, 16, 189194. 
DRY DEPOSITION IN INDIANAPOLIS

$(\mathrm{T}=26 \mathrm{C}, \mathrm{n}=4)$
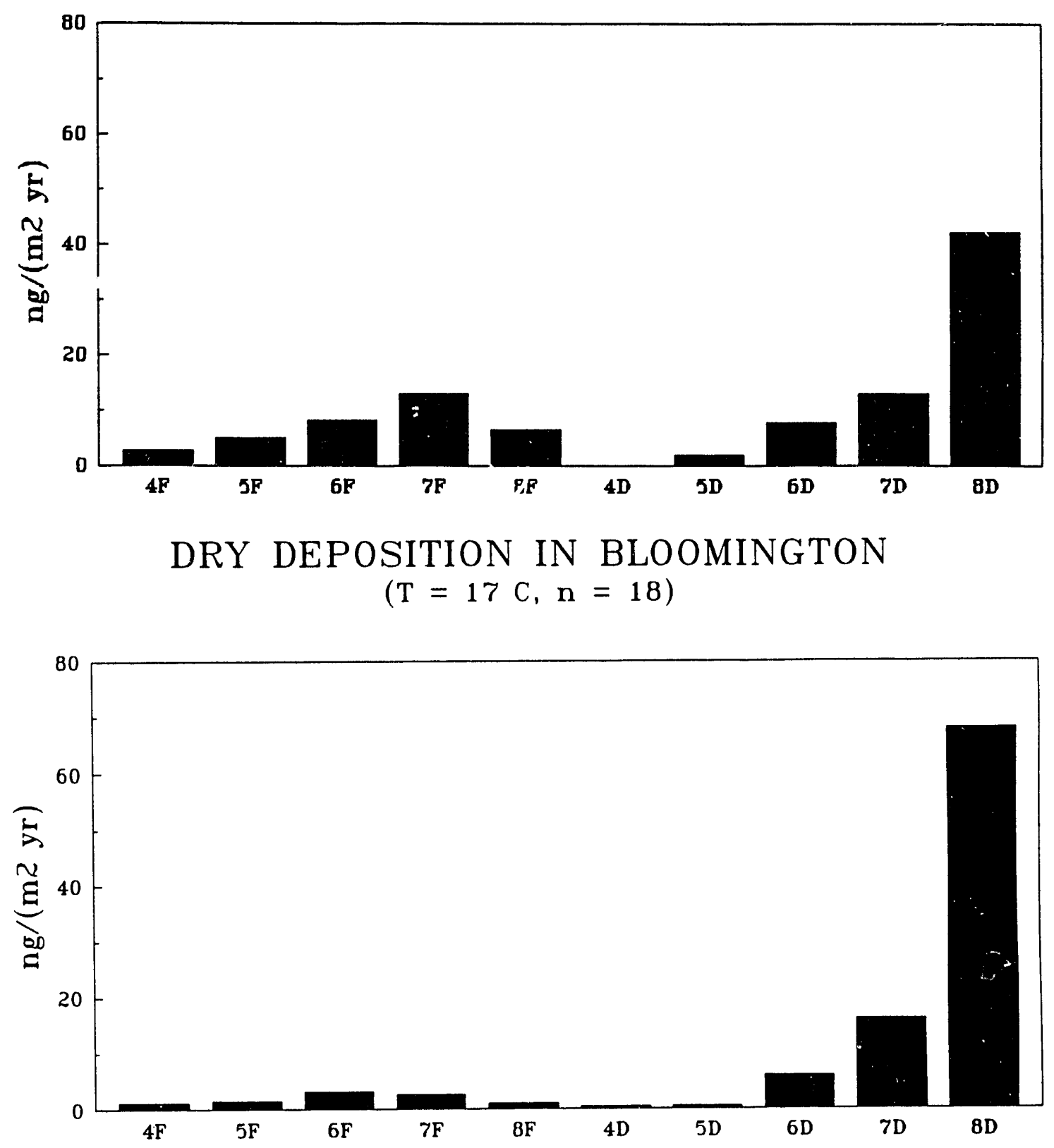

Figure 2. Average Indianapolis (top) and Bloomington (bottom) dry deposition profiles. $\mathrm{PCDD} / \mathrm{F}$ are quantitated as homologues and fluxes are in $\mathrm{ng} /\left(\mathrm{m}^{2} \mathrm{yr}\right)$. Numbers indicate level of chlorination. " $D$ " indicates PCDD and "F" indicates PCDF. 


\section{4. CHLORINATED DIOXINS AND FURANS IN SOIL NEAR ROADS: AN APPOR- TIONMENT OF MOBILE SOURCES}

Large stationary combustion systems, mainly municipal and hazardous waste incinerators, have long been considered the primary sources of polychlorinated dibenzo-p-dioxins and dibenzofurans (PCDD/F) (1). But they do not fully account for the levels we observe in the environment (2). The search for other sources continues. Recent investigation has focused on emissions from small combustion systems such as home heating and automobiles.

Automobiles may be a significant source of $\mathrm{PCDD} / \mathrm{F}$ for three reasons. First, they are widespread. United States' vehicle registrations numbered over 180 million in 1988 (3). Second, evidence suggests that any incomplete combustion in the presence of an organic chlorine source can lead to PCDD/F formation. Chlorine is a constituent of leaded fuel in the form of dichloromethane (a lead scavenger) and in unleaded fuels as a trace contaminant. Third, PCDD/F have been measured in automobile exhaust. The production rate of $\mathrm{PCDD} / \mathrm{F}$ was $315 \mathrm{pg} / \mathrm{km}$ in exhaust from light-duty vehicles burning commercial mixtures of unleaded fuels and $2760 \mathrm{pg} / \mathrm{km}$ in exhaust from vehicles burning leaded fuels (4).

Source apportionment is a problem in environmental science that is simple in concept but difficult in implementation. In our case the question is straight-forward; what is the relative contribution of automobile-generated PCDD/F to the environmental load of PCDD/F? The answer is not straight-forward. The extent to which automobile emissions contribute to $\mathrm{PCDD} / \mathrm{F}$ contamination is still unknown.

To address this issue, soil samples were taken at distances from 0 to 10 meters next to State Road 37 in Bloomington, Indiana. PCDD/F concentrations were determined by gas chromatographic, negative ion, mass spectrometry. Th. : soil concentrations of the tetra- through octachlorodibenzo-p-dioxins and of the penta- through heptachlorodibenzofurans decreased with increasing distance from the road's edge, suggesting vehicle emissions as the source of these compounds. The octachlorodibenzofuran concentration did not change significantly with distance, and the tetrachlorodibenzofuran concentration increased with distance from the road.

A typical homologue profile of roadside soil is shown in Fig. 1. Concentrations were not significantly different from average soil background levels reported in the literature (5) except for OCDD, which was significantly higher than background levels $(200 \mathrm{pg} / \mathrm{g})$, ranging from 900 to $5000 \mathrm{pg} / \mathrm{g}$. Estimates based on the 'evels of OCDD measured suggest that about $5 \%$ of all OCDD in soils in the United States may be found next to roads.

\section{References}

1. Olie, K; Vermuelien, P.L.; Hutzinger, O. Chemosphere, 1977, 6, 455-459.

2. Smith, R. M.; O'Keefe, P. W.; Aldous, K. M.; Valente, H.; Connors, S. P.; Donnely, R. J. Environ. Sci. Technol, 1990, 24, 1502-1506.

3. United States Department of Energy, Annual Energy Keview, 1990, 22.

4. $\quad$ Marklund, S,; Anderson, R.; Tyskland, M.; Rappe, C.; Egeback, K. E.; Bjorkma, E.; Grigoriadis, V. Chemosphere, 1990, 20, 553-561. 
5. Creaser, C. S.; Fernandes, A. R.; Al-Haddad, A.; Harrad, S. J.; Homer, R. B.; Skett, P. W.; Cox, E. A. Chemosphere, 1989, 18, 767-776.

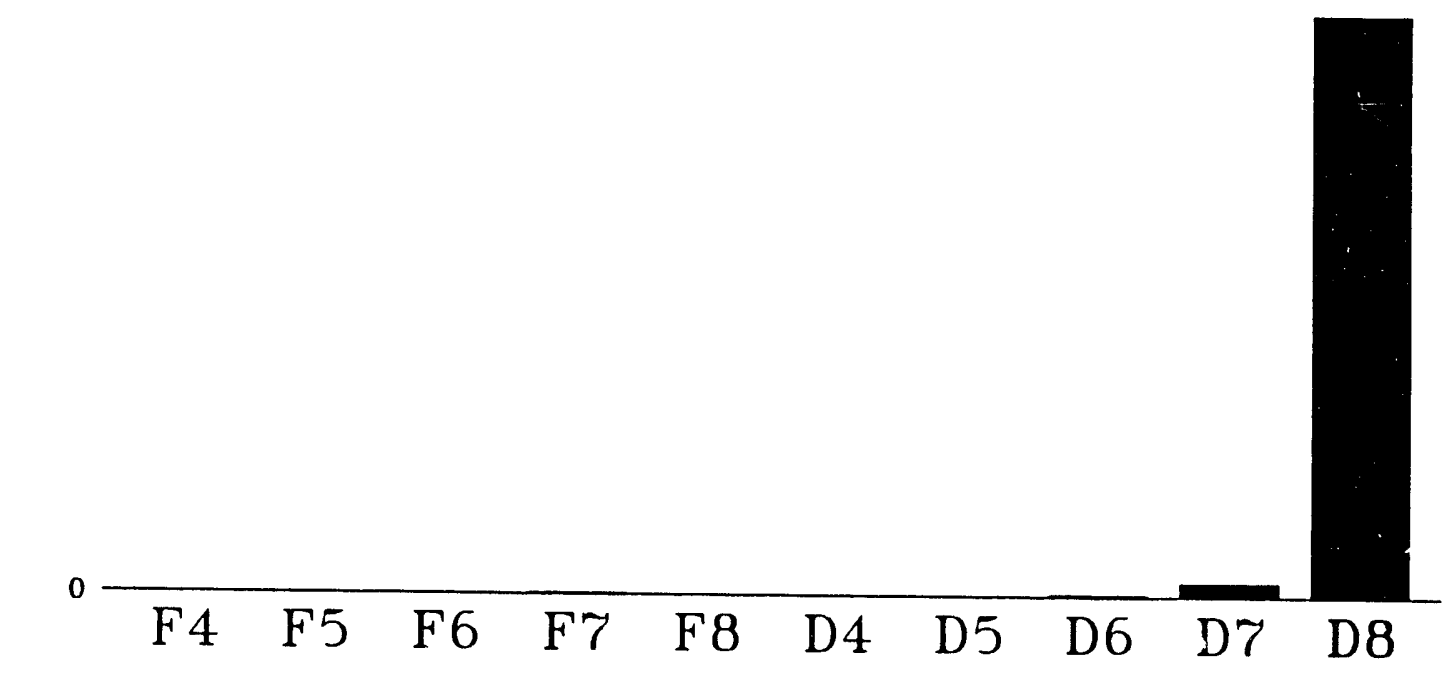

FIGURE. 1 Typical homologue profile of $\mathrm{PCDD} / \mathrm{F}$ in soil near roadway. 


\section{5. VAPOR PHASE PHOTOLYSIS OF CHLORINATED ORgANICS IN THE AT- MOSPHERE}

In our efforts to study the atmospheric processes which affect polychlorinated biphenyls (PCB), polychlorinated dibenzo- $p$-dioxins (PCDD), polychlorinated dibenzofurans (PCDF) and other chlorinated organics, we have begun to investigate the vapor phase photolysis of these species. Photodegradation is one pathway by which these compounds may be removed from the atmosphere. PCB and PCDD/F absorb light in the spectral region in which the sun emits radiation and at wavelengths greater than the ozone cut-off at $286 \mathrm{~nm}$. Therefore, it is possible that they degrade in the troposphere $(1,2)$.

Although previous studies have focused on PCB photolysis in solution (1), airborne PCB exist primarily in the vapor phase (3). Hence, it is important to understand their vapor phase photochemistry for a more realistic picture of their environmental fate. Atmospheric PCDD/F, on the other hand, are predominantly particulate bound (4). However, the lesser chlorinated species are present to a significant extent in the vapor phase (4). Photolysis of vapor phase 2,3,7,8-TCDD has been observed by Orth et al. (5) in the UV range from $250 \mathrm{~nm}$ to $320 \mathrm{~nm}$. In contrast, a lengthy study by our group showed that no appreciable photodegradation occurred for PCDD/F bound to fly ash. Clearly, a detailed study of the vapor phase photolysis of these compounds is essential to a complete understanding their atmospheric fate.

In our experimental arrangement, we have a quartz photolysis cell on line to a Hewlett Packard 5995A gas chromatographic mass spectrometer. The cell is situated in the GC oven and is connected to the injection and detection ports by surface-deactivated, fused silica capillary lines fitted to the cell by Swagelok reducing unions. Helium serves as the carrier gas, and the oven is held isothermally at $100^{\circ} \mathrm{C}$. A window was cut in the GC oven door to admit the light of a $450 \mathrm{~W}$, medium pressure, mercury vapor lamp. Although the window is currently left open (a shield around the lamp helps to insulate the oven), a WG $295 \mathrm{~nm}$ Schott glass cutoff filter is on special order from Melles Griot. This filter will act to simulate the ozone cut-off in the atmosphere when used as the window in the door.

We have chosen acetone as our gas phase actinometer to measure the performance of the system. To date, we have successfully monitored the ventilation rate of acetone from the cell in the absence of light $\left(t_{1 / 2}=35 \mathrm{~min}\right)$ as well as the rate of photolysis with the light on $\left(t_{1 / 2}=4 \mathrm{~min}\right)$. Both losses exhibit the expected first-order decay as described by the following equations:

$$
\begin{array}{ll}
\text { Light Off } & d I / d t=-k_{v} I \\
\text { Light On } & d I / d t=-\left(k_{v}+k_{p}\right) I
\end{array}
$$

where $I$ is the signal intensity, $k_{v}$ is the ventilation rate constant and $k_{p}$ is the photolytic rate constant. The disappearance of acetone in both cases is monitored using the ions at masses 43 and 58. Our future plans include a study of the vapor phase photolysis of a range of PCB and PCDD/F congeners beginning with 2,4,6-TCB and 1,2,3,4- and 2,3,7,8-TCDD. 


\section{References}

1. Bunce, N.J., Chemosphere 1982 11, 701-714.

2. Choudhry, G.G.; Hutzinger, O., Resid. Rev. 1982 84, 113-161.

3. Hermanson, M.H.; Hites, R.A., Environ. Sci. Technol. 1989 23, 1253-1258.

4. $\quad$ Eitzer, B.D.; Hites, R.A, Environ. Sci. Technol 1989 23, 1389-1395.

5. Orth, R.G.; Ritchie, C.; Hileman, F., Chemosphere 1989 18, 1275-1282. 


\section{6. THE USE OF TREE BARK AS A BIO NDICATOR FOK ATMOSPHERIC POLYCYCLIC AROMATIC HYDROCARBONS}

Although the bioaccumulation of inorganic air pollutants by tree bark has been studied, it was only recently that the study of tree bark bioaccumulation of organic air pollutants began. The early work in our laboratory focused on tree bark bioaccumulation of polychlorinated biphenyls (PCBs), which exist primarily as gases in the atmosphere (1, 2 ). The results of these early studies indicated that tree bark readily bioaccumulates vapor phase organic air pollutants, such as PCBs, due to the presence of suberin a complex fatty substance, in its outer bark. There is some question about whether the primary mechanism of bioaccumulation is due to the lipophilicity or vapor pressure of the organic compound under bioaccumulation (2).

To better understand the process of vegetative bioaccumulation, we have chosen to study a wide range of polycyclic aromatic hydrocarbons (PAH). These PAH have liquid phase vapor pressures ranging from $10^{-4}$ to $10^{-9}$ torr and molecular weights ranging from 178 to 276 daltons. Because of their wide range in vapor pressures, we sre able to study a single class of compounds in which some members exist primarily in the vapor phase (low molecular weight PAH) while others exist on particulates in the atmosphere (high molecular weight PAH). The PAH under investigation include phenanthrene, anthracene, fluoranthene, pyrene, chrysene, triphenylene, benz $[a]$ anthracene, benzo[e]pyrene, benzo[ $a]$ pyrene, indeno[1,2,3-cd] pyrene, and benzo[ghi]perylene.

Tree bark was collected from low, medium, and high traffic density sites in Bloomington, Indiana, and from Isle Royale, Michigan, according to previous methods (2). Samples were ground to particles less than $1 \mathrm{~mm}$ in diameter using a Udy Cyclone sample mill (Fort Collins, CO). Because the Soxhiet extraction and column chromatography cleanup procedures previously used $(1,2)$ are both labor intensive and time consuming, we have developed a supercritical fluid extraction (SFE) procedure using supercritical $\mathrm{N}_{2} \mathrm{O}$ and a cleanup procedure utilizing the $B \& J$ inert solid phase extraction (SPE) system (Muskegon, MI). This alternative txtraction and cleanup procedure is less time consuming, less labor intensive, and results in the use of less solvent than the previously used procedures.

The extraction is done off-line into a $25 \mathrm{ml}$ vial of hexane by packing a $250 \mathrm{~mm} \times 9.4$ $\mathrm{mm}, 17.3 \mathrm{ml}$ Keystone Scientific SFE cell (Bellefonte, PA) with approximately $7.0 \mathrm{~g}$ of ground bark and passing $300 \mathrm{ml}$ of supercritical $\mathrm{N}_{2} \mathrm{O}\left(325 \mathrm{~atm}\right.$ and $\left.50^{\circ} \mathrm{C}\right)$ through the cell. Figure 1 shows that the resultant recoveries are between 80 and 88 percent and that the low molecular weight PAH are more readily extracted than the high molecular weight PAH. The use of supercritical $\mathrm{N}_{2} \mathrm{O}$ instead of supercritical $\mathrm{CO}_{2}$ results in greater analyte recovery and extraction efficiency of high molecular weight PAH due to the presence of a dipole moment in $\mathrm{N}_{2} \mathrm{O}$. Analysis was done by electron impact gas chromatographic mass spectrometry and quantitation of PAH was accomplished using seiected ion monitoring.

To date, we have been successful in analyzing a sugar maple tree bark sample from the high traffic density site in Bloomington, IN. The concentrations of PAH in the sample range from 3 to $180 \mathrm{ng} / \mathrm{g}$ of bark (dry weight). These concentrations are comparable to 


\section{PERCENT RECOVERY vs VOLUME OF N2O}

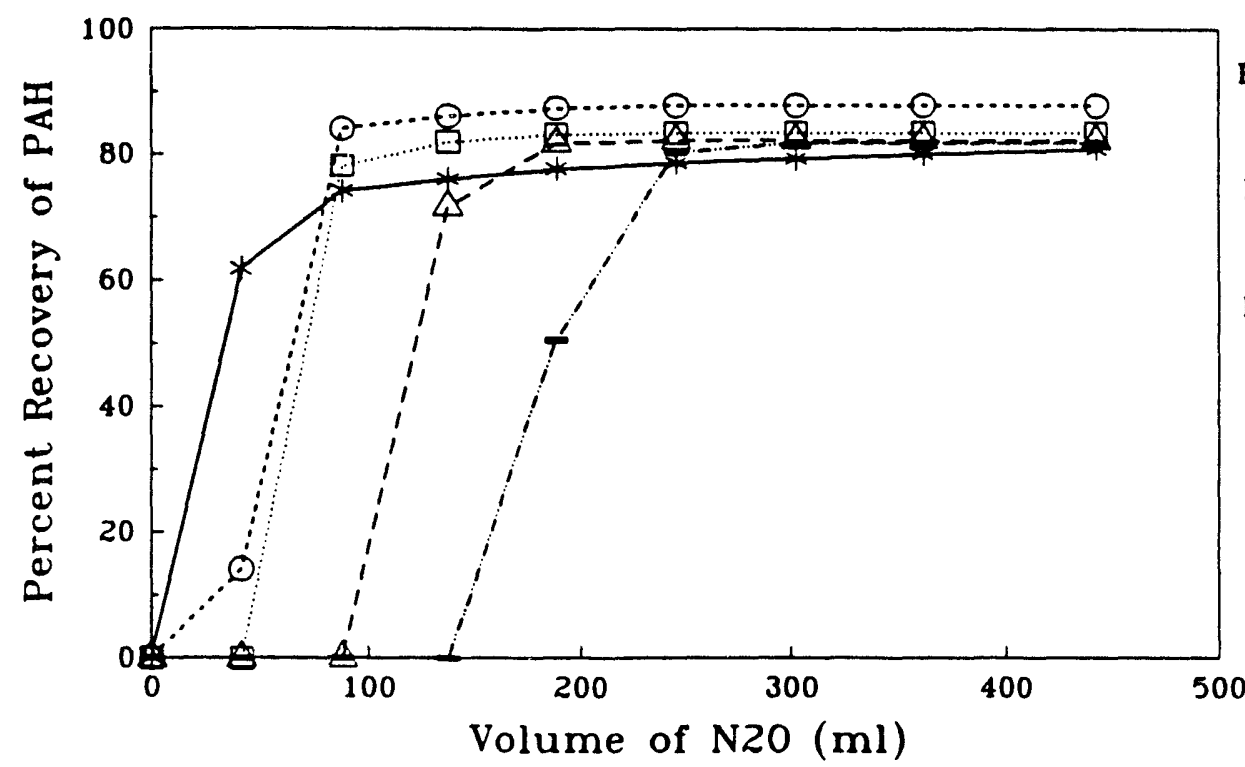

Molecular Wt. $=178$

Phenanth-Anthracene

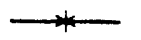

Molecular $\mathrm{Ft} .=202$

Fluoranthene-Pyrene ... $\odot . .$.

Molecular $\mathrm{Wt} .=22 \mathrm{~B}$

Benzlal-Chry-Triphen ………

Molecular Wt. $=252$

Benzolel-Benzolal $-\Delta-$

Molecular $\boldsymbol{T t}$. $=276$

Benzolghilperylene

$-\cdots-\cdots-\cdots$

Fig. 1. Plot of percent recovery of different molecular weight PAH verses the volume of supercritical $\mathrm{N}_{2} \mathrm{O}$ used. Percent recovery refers to the average recovery for that molecular weight.

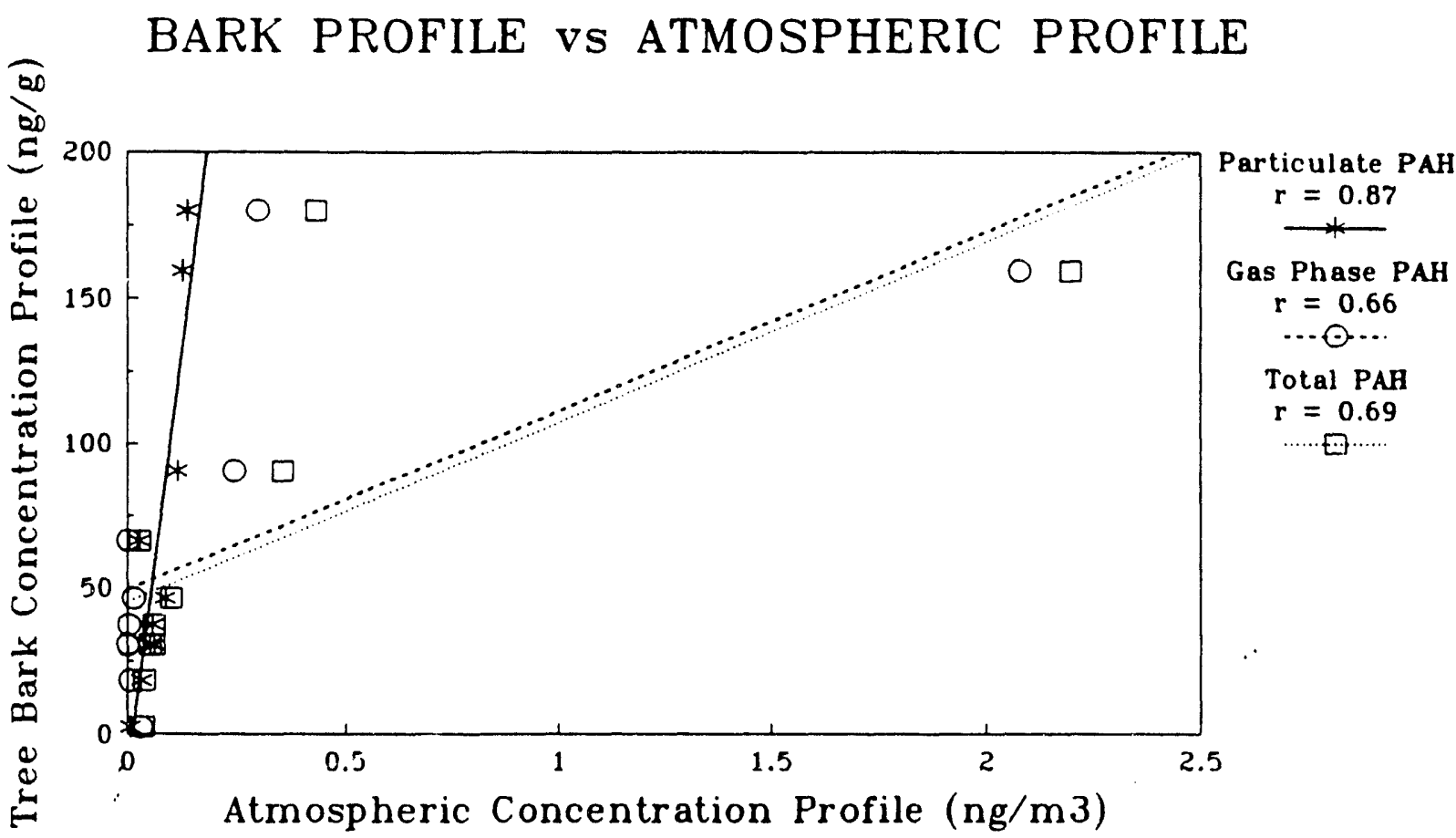

Fig. 2. Plot of the PAH concentration profile in Bloomington sugar maple tree bark verses a typical atmospheric particulate, gas phase, and total PAH profile. 
PAH levels found in kale plants and elm leaves exposed to low traffic densities for 5 to 6 months (3).

Because atmospheric PAH concentrations have never been accurately measured in Bloomington, we have correlated the sugar maple concentrations with Isle Royale atmospheric PAH concentrations (4). This correlation with atmospheric particulate, gas phase, and total PAH concentrations is shown in Figure 2. Although the absolute atmospheric concentration of PAH will undoubtedly be different in Bloomington than it is in Isle Royale, it can be assumed that the relative PAH profiles will be similar and that the Isle Royale profile may be used to represent a "typical" atmospheric PAH prcfile. Excellent correlation exists (less than the $1 \%$ level of significance) between the tree bark and the atmospheric particulate concentrations, while good correlation exists (the $5 \%$ level of significance) between the tree bark and atmospheric gas phase and total PAH concentrations. This may indicate that adsorption of particulate $\mathrm{PAH}$ plays a larger role in bioaccumulation than does absorption of gas phase PAH. Alternatively, it may simply indicate that the more lipophilic, higher molecular weight PAH are more readily bioaccumulated.

In order to further understand the role that lipid content plays in bioaccumulation, we are measuring the lipid content of each tree bark sample analyzed for correlation with PAH concentration. The lipid content of tree bark is species dependent and may even be a function of climate. For example, a Bloomington sugar maple has a lipid content of 40 $\mathrm{mg} / \mathrm{g}$ of bark, while a Bloomington white pine has a lipid content of $100 \mathrm{mg} / \mathrm{g}$ of bark.

A Bloomington white pine sample has been extracted, but attempts to use the cleanup procedure developed for sugar maples have failed. This appears to be due to the high lipid content in the white pine extracts which results in over loading of the column. The use of larger columns (1000 mg of silica instead of $500 \mathrm{mg}$ of silica) should solve this problem. It is important to be able to analyze high lipid content tree barks so that they may be compared to other bark types. Once we are able to analyze conifers, we should be able to analyze almost any type of tree bark.

Finally, we will be measuring the atmospheric concentrations of $\mathrm{PAH}$ in Bloomington for correlation with Bloomington tree bark samples. This will eliminate any difference that may exist in the atmospheric profiles of Bloomington and Isle Royale.

This study is significant because it will bring greater understanding to the process of vegetative bioaccumulation. This has implications not only for our food chain, but also to the equilibrium that exists between the atmosphere and pollutant sinks.

\section{References}

1. $\quad$ Meredith, M.L.; Hites, R.A. Environ. Sci. Technol. 1987, 21, 709-712.

2. Hermanson, M.H.; Hites, R.A. Environ. Sci. Techno!. 1990, 24, 666-671.

3. Brorstroem-Lunden, E.; Shaerby, L. Comm. Eur. Communities, [Rep.] EUR, EUR 9436, Phys.-Chem. Behav. Atmos. Pollut., 1984, 101-10.

4. McVeety, B. D. Atmospheric Deposition of Polycyclic Aromatic Hydrocarbons to a Water Surface: A Mass Balance Approach, Thesis, 1986. 


\section{7. A DIFFUSION DENUDER FOR THE COLLECTION OF SEMIVOLATILE ORGANIC COMPOUNDS FROM AMBIENT AIR}

A diffusion denuder is a tube, or a number of parallel or concentric tubes, the walls of which have been coated with a sorbent. When air is passed through the denuder tubes in a laminar flow stream, diffusion to walls of the tube is controlled by simple Brownian diffusion. Gas-phase molecules have diffusion coefficients in air that are 3 to 6 orders of magnitude higher than particulates. Thus, by adjusting the residence time of a parcel of air in the denuder tube, one can separate gases from particulates. Gas-phase molecules are collected by the sorbent on the walls of the denuder tube, and particulates are collected on a filter at the outlet of the sampling tubes.

We have constructed a diffusion denuder that uses capillary gas chromatographic columns as the sampling tubes. The sanpler consists of 120 tubes, $25 \mathrm{~cm}$ in length, cut from a DB-1 fused silica capillary column $(0.320 \mathrm{~mm}$ i.d., 5 micron film thickness). The sampler is designed so that the sampling tubes are parallel. The tubes are glued together with a thermally stable organic epoxy. The epoxy seals the spaces between the individual tubes and also provides mechanical rigidity to the sampler. After the epoxy cures, it is machined down to a smooth $3 / 8$ " diameter cylinder. The sampler can than be fitted with tubing fittings for connection to sampling pumps, etc.

Recent experiments have focused on examining the breakthrough characteristics of the denuder and also on comparing results from denuder experiments with results from parallel hi-vol experiments. Vapor/particle partitioning ratios and absolute concentrations have been compared.

A diesel exhaust sample was collected with this sampler to examine breakthrough. For this experiment a conventional filter/PUF sampler was located behind the denuder in the sampling stream. Air was drawn through the sampling train at $2 \mathrm{~L} / \mathrm{min}$ for $20 \mathrm{~min}$ using a small personal sampling pump. After sample collection, the sampler was thermally desorbed off-line into a vial of methylene chloride. The filter and PUF plugs were extracted by sonication in methylene chloride. All samples were spiked with $\mathrm{d}_{10}$-pyrene as an internal standard and analyzed using electron impact mass spectrometry.

The presence of a series of $n$-alkanes in the sample allowed identification of compounds by retention index. Furthermore, we can use retention index as a surrogate for vapor pressure to understand breakthrough in this sampler. Figure 1 shows the percent collected on the denuder (\%denuder divided by the sum of \%denuder plus \%filter plus $\%$ PUF) as a function of retention index. The data shows three distinct regions. The first region is composed of all compounds having retention indices less than 1300 . This is the region where breakthrough is occurring. Compounds eluting in this region are in the gas phase, but are too volatile to be collected in the denuder. They pass through and are collected on the PUF. The second region is from approximately 1300 to 1600 . This region shows quantitative retention of gas-phase molecules in the denuder, but no vapor/particle partitioning. The region greater than 1600 is where vapor/particle partitioning is important. Gas-phase molecules in this region are quantitatively retained on the denuder, while particulates pass through and are collected on the filter. 
Future experiments are focused on determining the optimum design, construction, and operating conditions for the denuder. The range of conditions for which this sampler will be effective must be determined prior to its use for applied studies. Design variables such as tube length, sorbent thickness, tube inner diameter, and the number of tubes will be studied. These design variables will be tested by building a number of new samplers, then comparing the results obtained from samples collected concurrently with traditional PUF/filter samplers.

Diesel Exhaust

\% on Denuder vs Retention Index

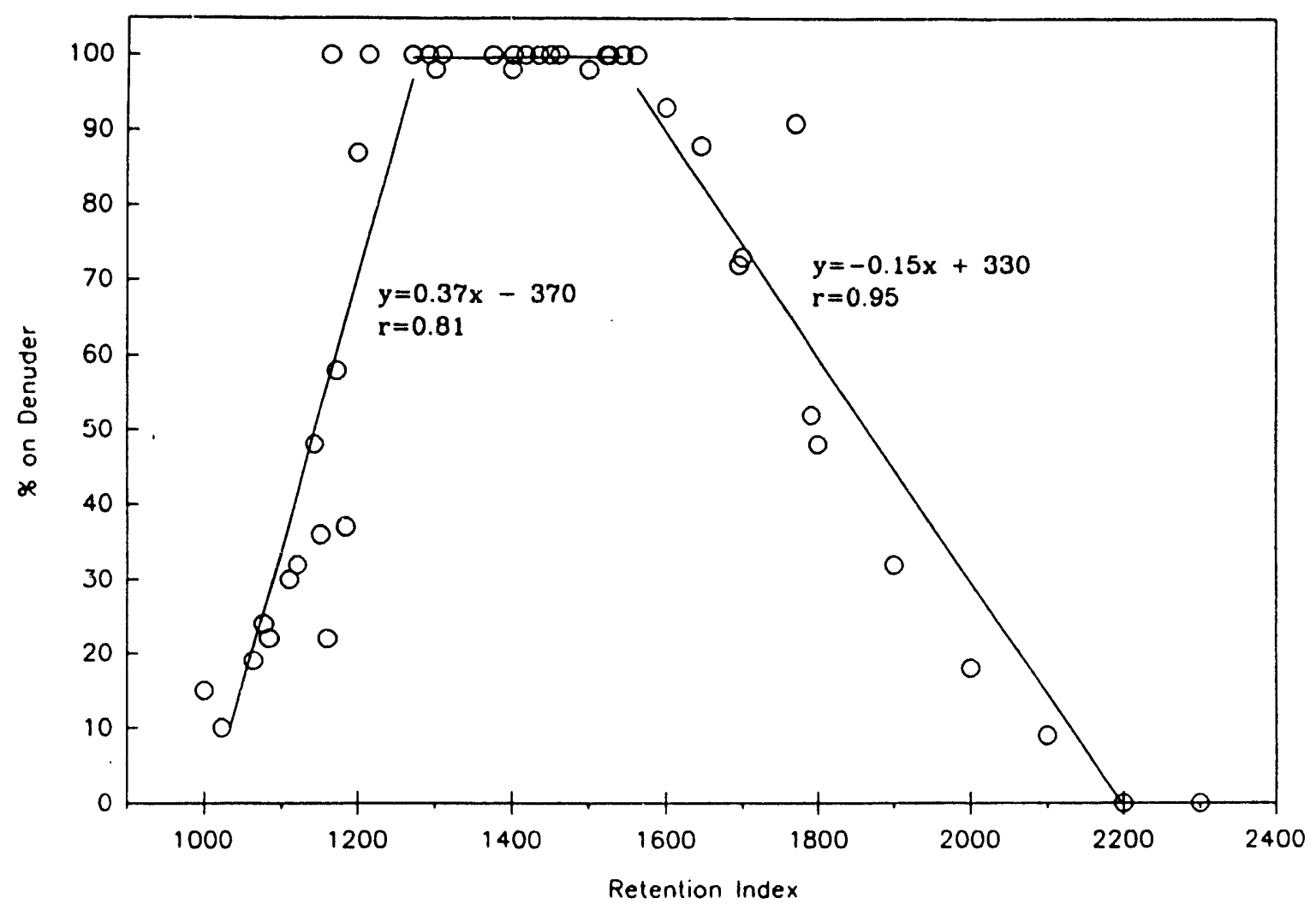

Figure 1. Percent of a compound collected on the denuder as a function of retention index, which is inversely proportional to vapor pressure. The sample was taken $0.2 \mathrm{~m}$ from the exhaust of a diesel bus. 

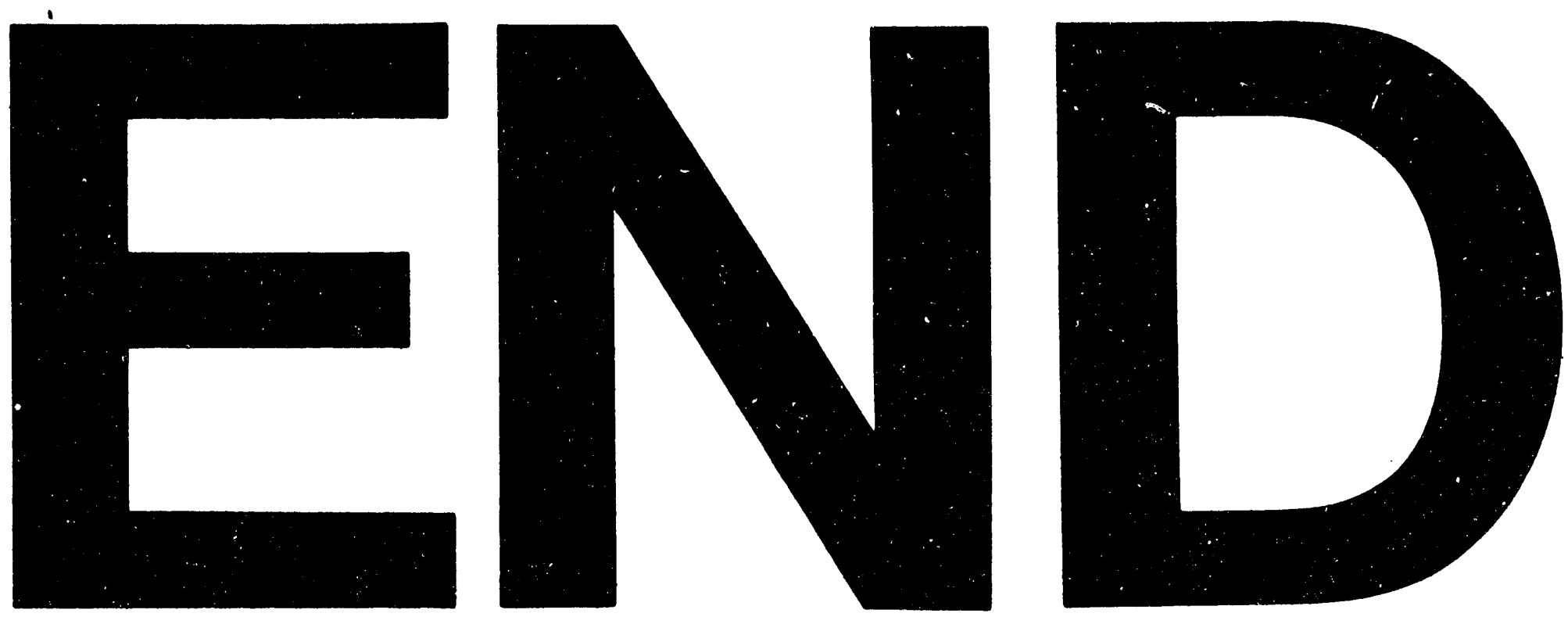

$\because$

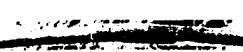

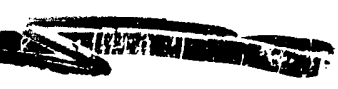

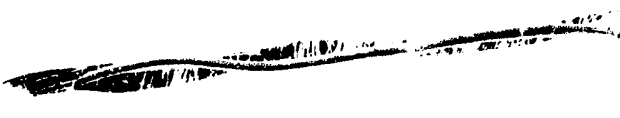

